\title{
Invers Modeling Gravity Data for Semi-Infinite Slab Using Matlab
}

\author{
A. Adhi ${ }^{1,2 *}$, Sismanto ${ }^{2}$, A. Setiawan ${ }^{2}$ \\ ${ }^{1}$ Program Studi Fisika, Universitas Negeri Semarang, Indonesia \\ ${ }^{2}$ Program Studi Fisika, Universitas Gadjah Mada, Indonesia
}

Received: 2 March 2019. Accepted: 29 May 2019. Published: 1 July 2019

\begin{abstract}
Semi-infinite slab modeling has been made through inverse data gravity using Matlab. Inversion of gravity data is done by first determining the simulation data. Forward modeling uses simulation data to produce an initial guess inversion model expressed with parameters n0 (1), n0 (2), n0 (3) and n0 (4). The forward modeling is performed on the next initial guess that the value of the misfit is as small as possible through an iteration using the Jacobian matrix. Accuracy of inversion results is determined by the initial guess and the number of iterations. The results obtained show that inversion modeling is more valid in the inversion modeling process compared to advanced modeling, because the value of the parameters sought is generated from mathematical observations of the observation data. Guesses greatly affect the results of inversions obtained. Initial guesses are given in the form of parameters n0 (1), n0 (2), n0 (3) and n0 (4). The initial guess for the parameters n0 (1), and n0 (2) that are made far deviant does not affect inversion. The initial guess for the parameters no (3), and n0 (4) that are made deviating far influences the inversion caused by a very small RCON value so that the result is NAN.
\end{abstract}

\begin{abstract}
ABSTRAK
Telah dibuat pemodelan semiinfinite slab melalui inversi data gravitasi dengan menggunakan Matlab. Inversi data gravitasi dilakukan dengan membandingkan akuisisi data dan perhitungan teoritis. Akuisisi data disusun melalui tahapan forward modeling data sintetik dengan menambahkan error. Model tebakan awal inversi dinyatakan dengan parameter $\mathrm{nO}(1), \mathrm{n} 0(2), \mathrm{n} 0(3)$ dan $\mathrm{nO}(4)$. Nilai misfit sekecil mungkin melalui iterasi dengan menggunaan matriks Jacobian antara model tebakan awal dan model recovered. Ketelitian hasil inversi ditentukan oleh tebakan awal dan banyaknya iterasi. Hasil yang didapatkan menunjukkan pemodelan inversi lebih valid dalam proses pemodelan inversi dibandingkan dengan pemodelan maju, karena nilai parameter yang dicari dihasilkan dari olah data observasi secara matematis. Tebakan sangat mempengaruhi hasil inversi yang didapatkan. Tebakan awal diberikan dalam bentuk parameter n0(1), $\mathrm{n} 0(2), \mathrm{n} 0(3)$ dan $\mathrm{n0}(4)$. Tebakan awal untuk parameter $\mathrm{n0}(1)$, dan $\mathrm{n0}(2)$ yang dibuat menyimpang jauh tidak mempengaruhi inversi. Tebakan awal untuk parameter $\mathrm{n0}(3)$, dan $\mathrm{n} 0$ (4) yang dibuat menyimpang jauh mempengaruhi inversi yang diakibatkan nilai RCON yang sangat kecil sehingga hasilnya berupa NAN.
\end{abstract}

Keywords: Gravity data; Inversion; Semi-infinite slab.

\section{INTRODUCTION}

There several way to solve invers modeling data gravity (Supriyadi, 2009). A new gravimetric data inversion method for a linear problem (reconstruction of the density distribution by a gravitational field). It is an iterative algorithm based on the concept of local correction

\footnotetext{
${ }^{*}$ Correspondence Address:

Kampus Sekaran Gunungpati, Semarang 50229, Indonesia E-mail : aryono_adhi@yahoo.com
}

(also called method) (method correction) (Martyshko, Ladovskii, Byzov, \& Tsidaev, 2018). The slope filter is an interpretation method used to determine the source near the location based on the potential field data. (Eshaghzadeh, 2017) The inversion algorithm was developed to simultaneously evaluate the geometry of the error field and density or depth related parameters of various geological structures in a system of suspended walls, based on obstacles. limited electric. because of the obser- 
ved gravitational deviations by (Chakravarthi \& Kumar, 2015). It was verified and verified by a theoretical model, if there were random errors (Abdelrahman \& Essa, 2013). A new approach to determining the semi-initial depth of the plate with respect to gravitational deviations remains the moving average (Abdelrahman \& Essa, 2013). The inverse transformation method is used to simulate gravity differences as density objects, which vary with the depth of the local value using the average kernel configuration, and apply them to specific cases. specific error. geological (Yapa, Tantrigoda, \& Pathirana, 2016). The inverse problem is solved by determining all the parameters described by the field source for the experimental data. If the unknown parameter is density or magnetization, this type of problem is linear and, in many cases, is an uncertain task because the amount of data is less than the number of unknown parameters. One can reduce ambiguities by specifying the use of boundaries defining geology-based models, such as the maximum variation range of model parameters (Vitale, Massa, Fedi, \& Florio, 2015). The gravity method is based on the measurement of the gravity anomaly caused by a density fluctuation caused by an abnormal source of existence of a potential object in the form of a semi-infinite plate by the gravity method. The gravity method should be able to clarify the existence of a future object in the form of a gravitational anomaly. Gravimetric data can be used to detect gravitational deviations. The inverse simulation of semi-infinite plates is based on a comparison of the effect of a gravitational plate (Abdelrahman \& Essa, 2013; Essa, 2014).
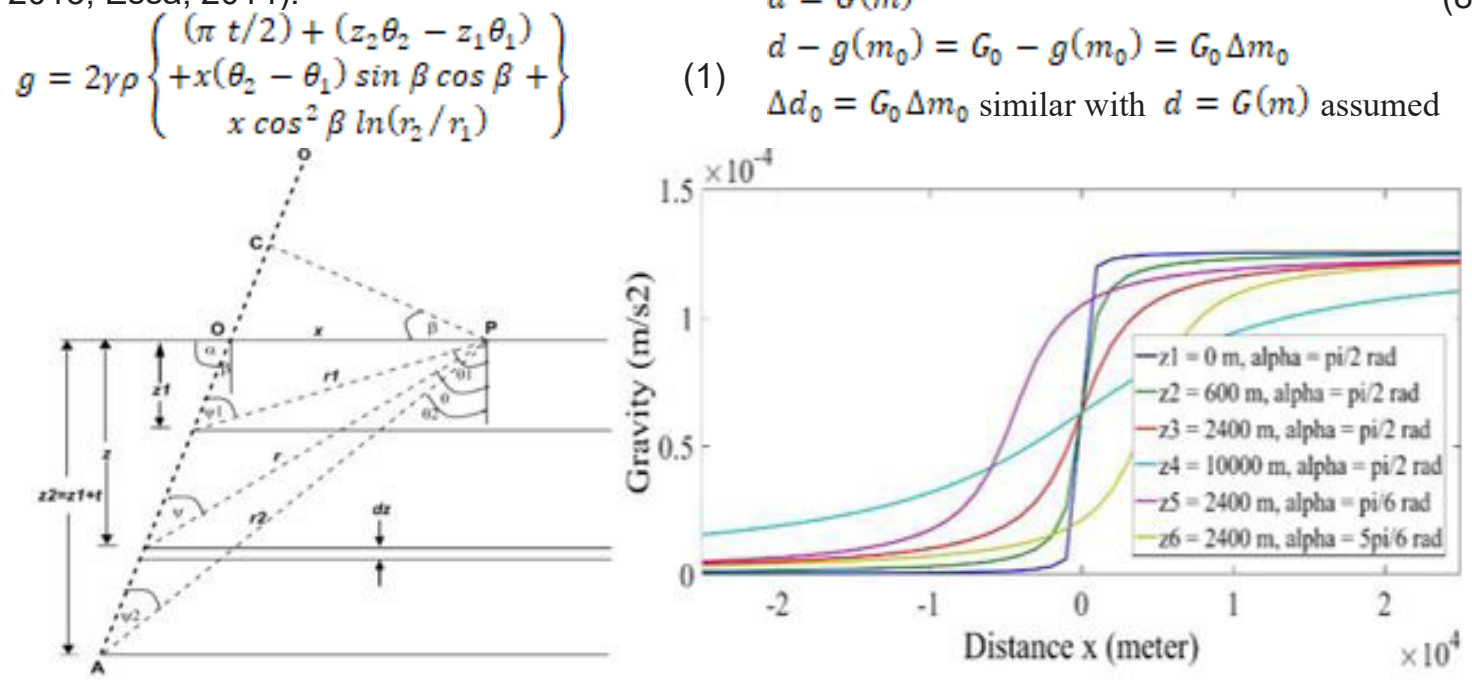

Figure 1. Gravity effect vs station distance for semiinfinite horizontal slab. Gravity effect vs station distance for semi-infinite horizontal slab $t=300 \mathrm{~m}$, with upper depth slab variation $z_{1}=0 \mathrm{~m}, 600 \mathrm{~m}$, $2400 \mathrm{~m}$ dan $10000 \mathrm{~m}$ with fault dipping at $\pi / 2, \pi / 6,5 \pi / 6$, dan $\rho=1000 \mathrm{~kg} / \mathrm{m}^{3}$

The general inversion equation is:

$d=g(m)$

$$
\left[\begin{array}{c}
d_{1} \\
\vdots \\
d_{N}
\end{array}\right]=\left[\begin{array}{c}
g_{1}\left(r h o, z_{1}, z_{2}, \beta\right) \\
\vdots \\
g_{n}\left(r h o, z_{1}, z_{2}, \beta\right)
\end{array}\right]
$$

the local value using the average kernel configuration, and apply them to specific cases. specific error. geological (Yapa, Tantrigoda, \& Pathirana, 2016). The inverse problem is solved by determining all the parameters described by the field source for the experimental data. If the unknown parameter is density or magnetization, this

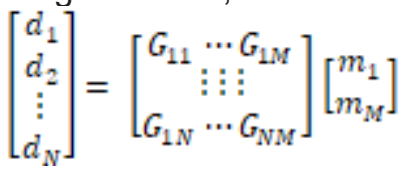

with with $m_{1}=$ rho, $m_{2}=z_{1}, m_{3}=z_{2}$ and $m_{4}=\beta$, so the equation $m$ becomes $m=\operatorname{inv}\left(G^{T} \cdot G\right) G^{T}$.

The matching method can be formulated as follows:

$m=m_{0}+\Delta$.

$d=G(\mathrm{~m})$

with the Taylor expansion equation being

$d_{i}=g_{i}(m) \approx g_{i}\left(m_{0}\right)$

$+\sum_{j=1}^{M}\left[\frac{\partial g_{i}(m)}{\partial m_{j}} \mid \Delta m_{j}\right]$

with $\mathrm{i}=1,2, \ldots, \mathrm{N}$ and $\mathrm{j}=1,2, \ldots, \mathrm{M}$ and $\mathrm{N}$ is the number of data and $M$ the number of parameters then $\Delta \mathrm{m}_{1}$ is $\Delta \rho, \Delta z_{1}, \Delta z_{2}, \Delta \beta$. With the rearrangement, then Taylor's expansion equation becomes:

$d=G(\mathrm{~m})$

$d-g\left(m_{0}\right)=G_{0}-g\left(m_{0}\right)=G_{0} \Delta m_{0}$

$\Delta d_{0}=G_{0} \Delta m_{0}$ similar with $d=G(m)$ assumed 
$\Delta d_{0}=d-g\left(m_{0}\right)$ then the inverse equation is:

$\Delta m_{0}=\operatorname{inv}\left(G_{0}^{T} G_{0}\right) G_{0}^{T}\left(d-g\left(m_{0}\right)\right)$

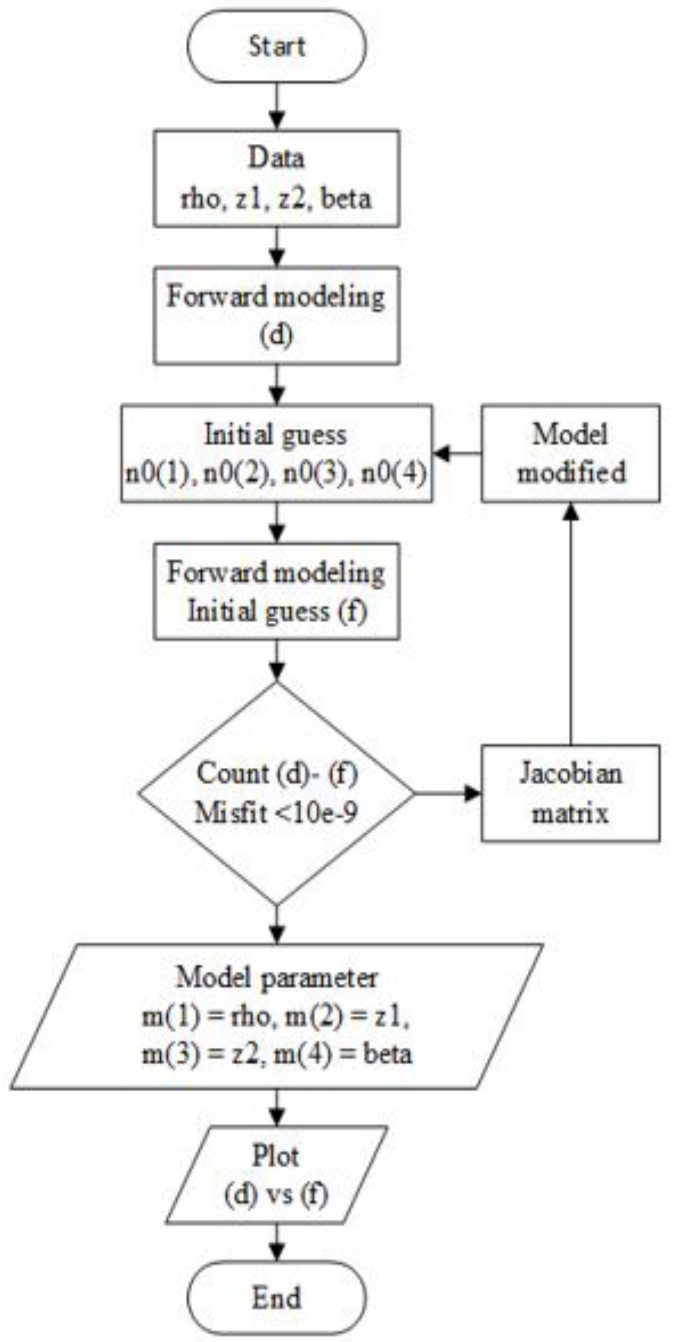

To obtain suitable results, the calculation process is done iteratively until convergent results are obtained.

The $G$ which is the Jacobi matrix consists of $G=\left[\begin{array}{llll}G_{\rho} & G_{z_{1}} & G_{z_{2}} & G_{\beta}\end{array}\right]$

$G_{n}^{T}$ is a transfer matrix for each parameter in the $n$ iteration, $d$ is data and $g\left(m_{0}\right)$ is the result of the calculation of the model from the inversion calculation.

\section{METHOD}

The physical model applied for testing the inversion program in the form of semi-infinite slab with physical parameter density in $\mathrm{kg}$ per cubic $m=1000$, depth of the upper side of the slab in meters $=200$, depth of the slab bottom in meters $=700$, slope angle in radians $=30$ (Figure 1).

The initial guess is given with a variation of the deviation value approaching the value of the physical parameter until the value is away from the value of the physical parameter (Equation (1) and (2)). The gravity response of the physical model is expressed as theoretical data. Theoretical data is the result of calculating forward modeling without a random error added using Equation (3) to (10).

Subsequent tests are carried out using synthetic data. Synthetic data is forward modeling calculation data by adding random errors that represent field data. The non-linear inversion modeling algorithm with a linear approach is shown as follows (Figure 2).

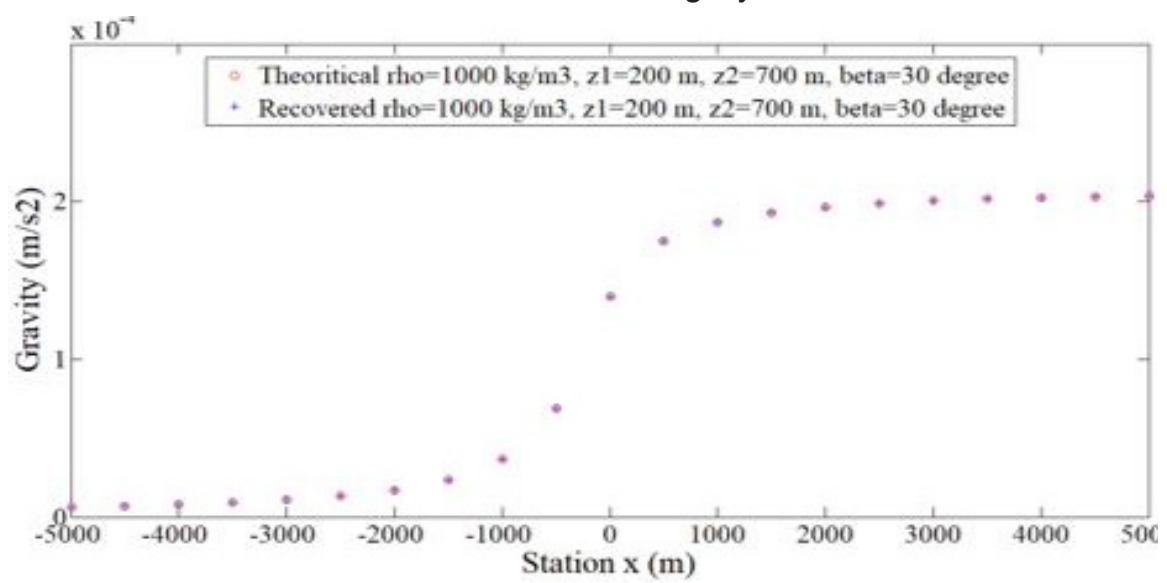

Figure 3. Data gravity inversion results with an initial guess no $=[1 ; 200 ; 700 ; 30$ *pi. / 180] 
modeling are obtained modeling results with appropriate results between the foward model and the inverse model. The initial guess really determines the number of iterations done. In this programming the values for 4 semi-ifinite slab horizontal parameters are density, upper edge depth, bottom edge depth, and slab angle formed against outcrop (Eshaghzadeh, 2017; Vitale et al., 2015; Yapa et al., 2016)

The program test is carried out by giving a variety of initial guesses. Variations carried out include the value of density, upper side depth, bottom side depth and slab angle. The initial guess is by varying the deviant density values as far as possible from the model parameters in the $3^{\text {rd }}$ iteration, producing a density in $\mathrm{kg}$ per cubic $\mathrm{m}=1000$, the depth of the upper side of the slab in meters $=200$, the depth of the bottom side of the slab in meters $=700$, slope angle slab in radians $=30$. with an error $=$ 0,00064214 in the $3^{\text {rd }}$ iteration (Figure 3 ).

The initial guess by varying the side depth values of the slab deviates as far as possible from the model parameters in the 9th iteration, producing a density in $\mathrm{kg}$ per cubic $m=1000$, the depth of the upper side of the slab in meters $=200$, the depth of the bottom side of the slab in meters $=700$, slope angle slab in radians $=30$ with a propagation error $=$
0,00026528 in the $6^{\text {th }}$ iteration (Figure 4).

The initial guess by varying the depth of the bottom side of the slab deviates as far as possible from the model parameters in the $21^{\text {st }}$ iteration, the density in $\mathrm{kg}$ per cubic $\mathrm{m}=1000$, the depth of the upper side of the slab in meters $=200$, the depth of the bottom side of the slab in meters $=700$, slab slope angle in radians $=$ 30 with propagation error $=0,00019328$ in $14^{\text {th }}$ iteration (Figure 5).

The dependence of $z 1$ and $z 2$ on slab slope formulated in the form of $\tan ^{-1}\{(x+z \tan \beta) / z\}=\theta$ makes the initial guesses z1 and z2 distorted for beta values small still produces a small error.

For example, the initial guess for the initial model is $\mathrm{nO}=[1000 ; 2 ; 2000 ; 3$ * pi. / 180 ] producing a density in $\mathrm{kg}$ per cubic $\mathrm{m}=$ 996,4576 , the upper side slab depth in meters $=199,9266$, the depth of the bottom side of the slab in meters $=700,0387$, slab slope angle in degrees $=29,9991$, with an error $=0,0017$ (Figure 6). The second test uses the initial guess n0 = [1000; $2 ; 350 ; 30$ * pi. / 180] with $z 2$ which is far deviant gets an error 0,00018937, with recovered rho $=999,999 \mathrm{~kg}$ per cubic meter, $z 1=199,9994 \mathrm{~m}, \mathrm{z} 2=700,0008 \mathrm{~m}$, beta $=$ 30 degree (Figure 7). The second test results show that the Matlab script used for semi infi-

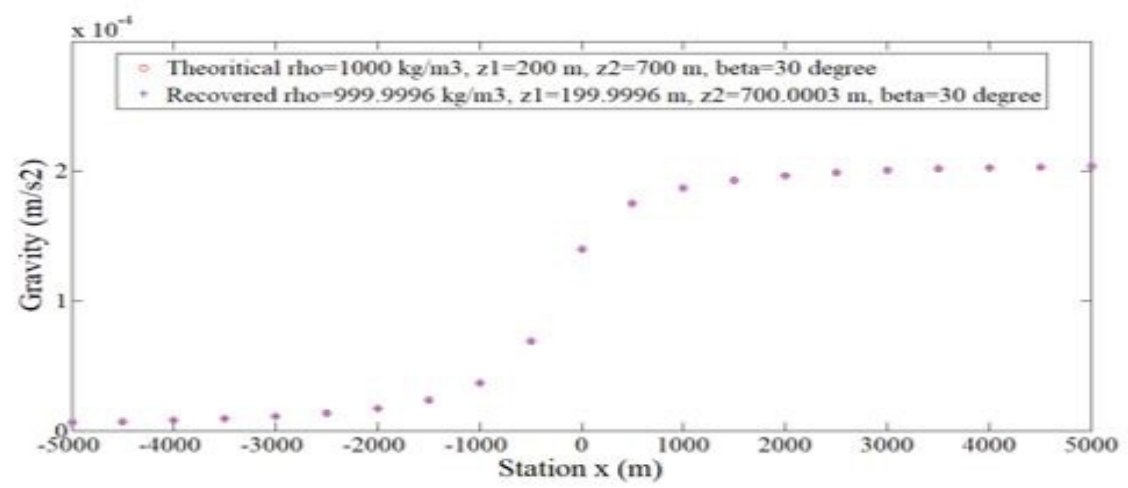

Figure 4. Data gravity inversion results with an initial guess no $=\left[1000 ; 1 ; 700 ; 30^{*}\right.$ pi. $\left./ 180\right]$

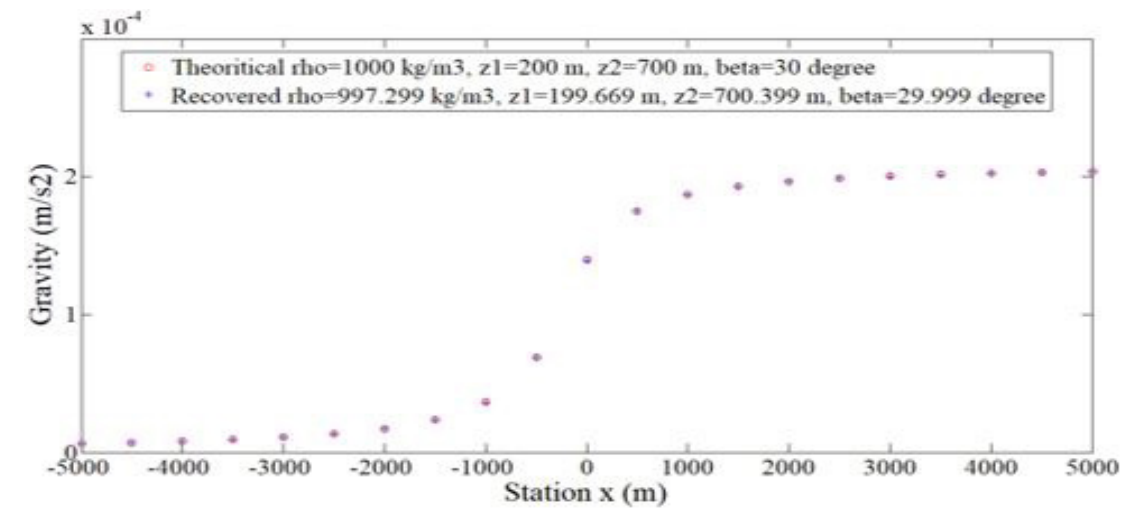

Figure 5. Data gravity inversion results with an initial guess $n 0=\left[1000 ; 200 ; 548 ; 30^{*} \mathrm{pi} / 180\right]$ 


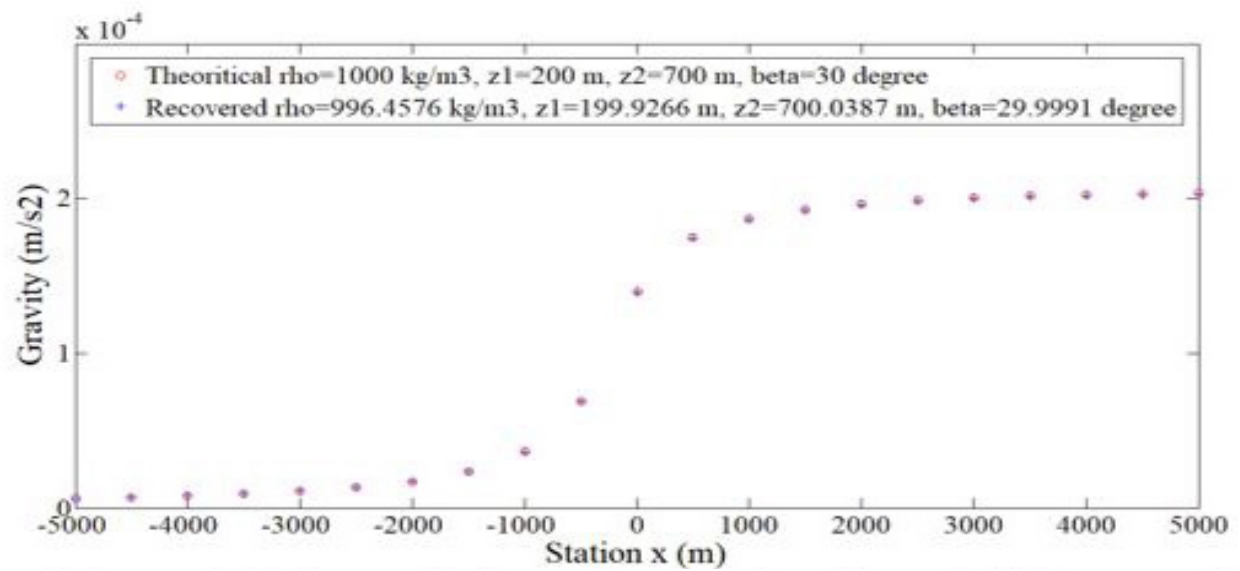

Figure 6. Data gravity inversion results with an initial guess no $=\left[1000 ; 2 ; 2000 ; 3^{*}\right.$ pi./180]

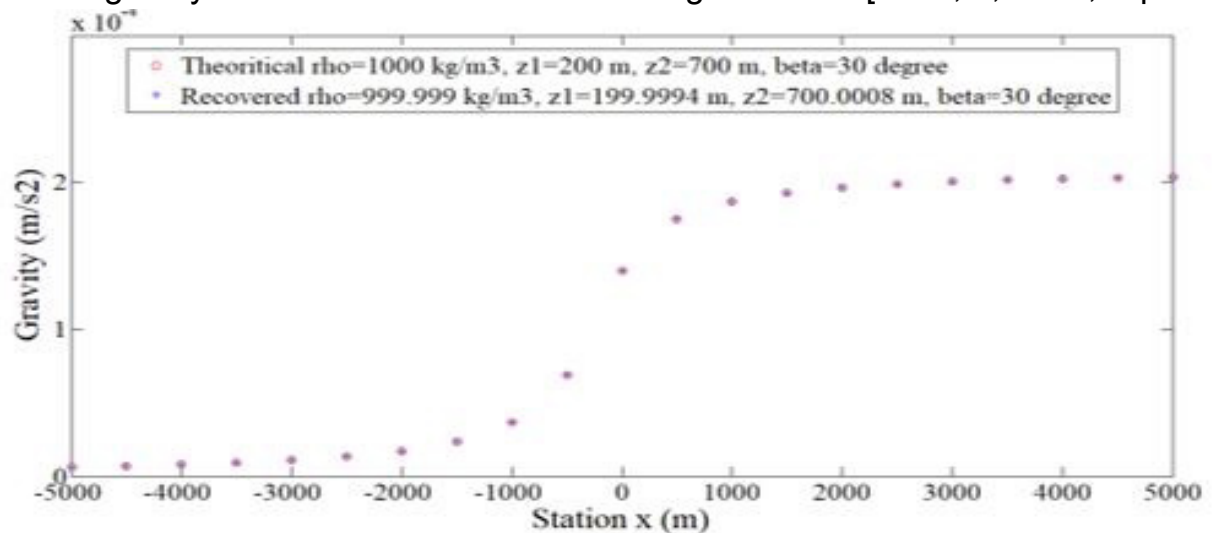

Figure 7. Data gravity inversion results with an initial guess no $=\left[1000 ; 2 ; 350 ; 30^{*}\right.$ pi. /180]

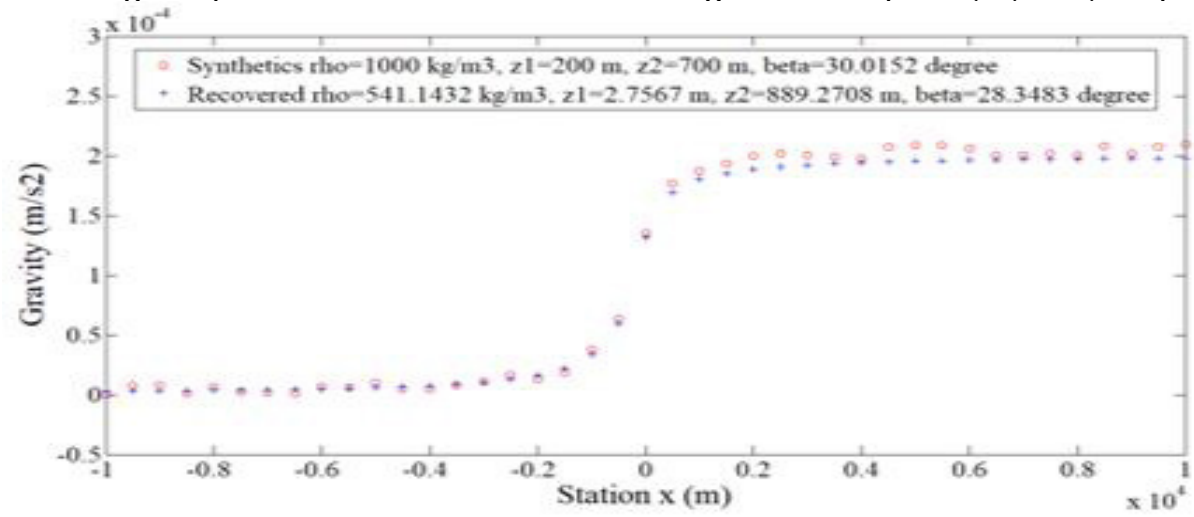

Figure 8. Data gravity inversion results with an initial guess no $=\left[1000 ; 1 ; 1000 ; 1^{*}\right.$ pi. /180]

nite slab inversion data gravity is stable. Next is the semi infinite slab gravity data inversion program test using synthetic data. Synthetic data is created using theoretical data such as those used in the previous test by adding random errors. Random value $r=$ rand (1.41); er $=(r-0.5) .{ }^{*} 0 ; 0000075$ by setting $d=d 1+1.5$ * (er) in the forward modeling script. Inversion is done by setting various initial models. The initial test was carried out using the initial model n0 $=[1000 ; 1 ; 1000 ; 1$ * pi. / 180]. The recovered model has a density in $\mathrm{kg}$ per cubic $\mathrm{m}=$ 541,1432 , the upper side slab depth in meters
$=2,7567$, the depth of the slab bottom in meters $=889,2708$, slab slope angle in degrees $=$ 28,3483 with propagation error $=0,00013827$ in the $1^{\text {st }}$ iteration, error $=0,00014162$ in the 2nd iteration, error $=0,00021419$ in $3^{\text {rd }}$ iteration, error 0,00012630 in $4^{\text {th }}$ iteration and error 0,0000043903 in $5^{\text {th }}$ iteration. The second stages with successive RMS 0,000027187 The second test is done using the initial model deducted $20 \%$ from the original model parameters obtained with the initial model $\mathrm{n} 0=$ [800; 160; 560; $24^{*}$ pi. /180]. Recovered rho $=$ $1024,0634 \mathrm{~kg}$ per cubic meter, $z 1=167,8169$ 


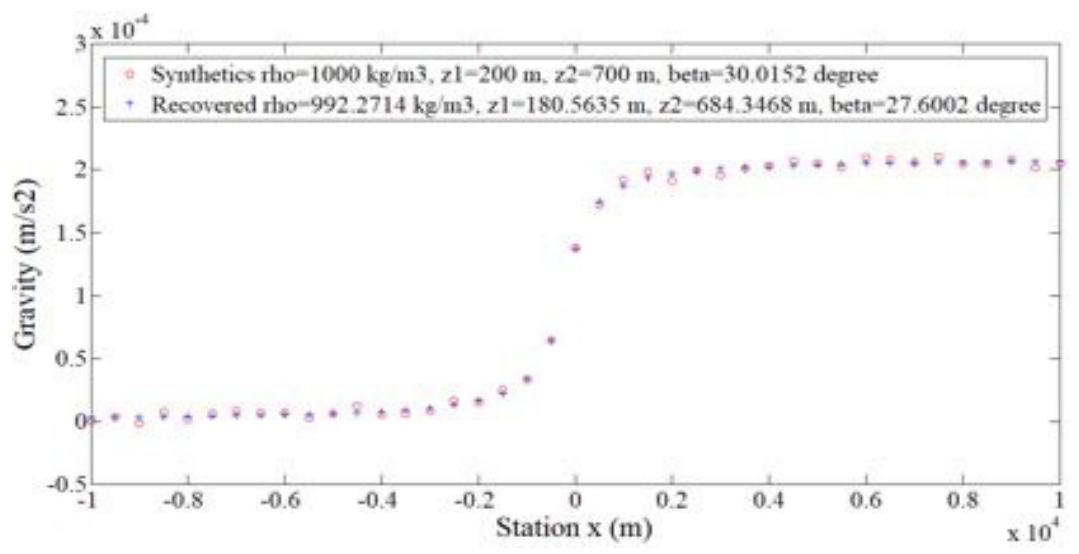

Figure 9.Data gravity inversion results with initial guesses $\mathrm{n} 0=\left[900 ; 180 ; 660 ; 27^{*}\right.$ pi. /180]

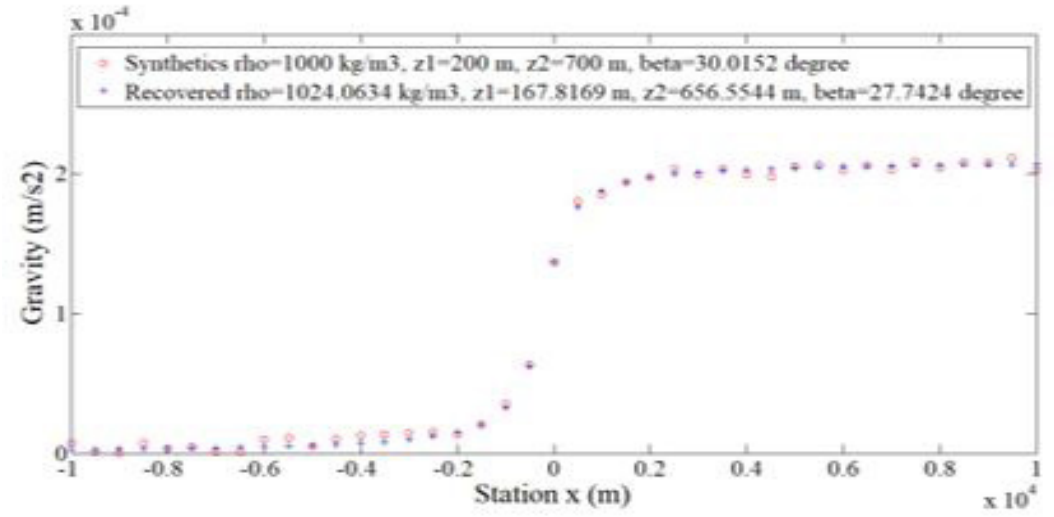

Figure 10. Data gravity inversion results with initial guesses $n 0=\left[800 ; 160 ; 560 ; 24^{*}\right.$ pi. $\left./ 180\right]$

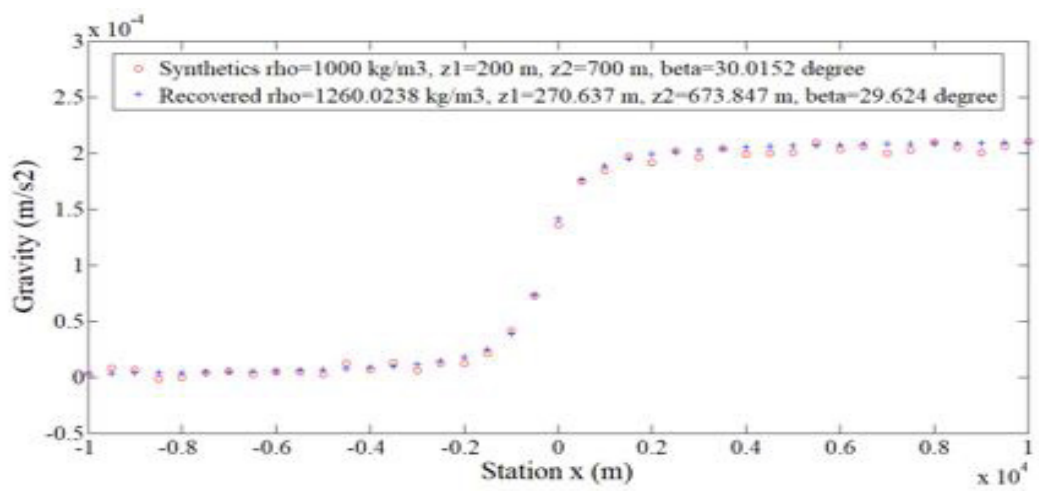

Figure 11. Data gravity inversion results with an initial guess no $=1200 ; 280 ; 840 ; 36^{*}$ pi. /180]

$\mathrm{m}, \mathrm{z2}=656,5544 \mathrm{~m}$, beta $=27,7424$ degree with errors achieved successively 0,00005151 dan 0,000009052 .

and 0,0000034068 . Test is carried out using the initial guess parameter subtracted $10 \%$ from the original parameters so that the initial model is obtained with $\mathrm{n} 0=[900 ; 180$; $660 ; 27^{*} \mathrm{pi}$. /180]. The model produced through inversion has recovered rho $=992,2714 \mathrm{~kg}$ per cubic meter, $\mathrm{z} 1=180,5635 \mathrm{~m}, \mathrm{z2}=684,3468$ $\mathrm{m}$, beta $=27,6002$ degree through two iterative step.

The second test is carried out using the initial model $n 0=\left[1200 ; 280 ; 840 ; 36^{*}\right.$ pi. /180]. Recovered rho $=1260,0238 \mathrm{~kg}$ per cubic meter, $z 1=270,637 \mathrm{~m}, \mathrm{z} 2=673,847 \mathrm{~m}$, beta $=$ 29,624 degree RMS $=0,000051518$ RMS $=$ 0,0000090526, RMS $=0,000049616$, RMS $=$ $0,000026491, \mathrm{RMS}=0,000012164, \mathrm{RMS}=$ 0,0000055937

Referring to the results obtained, the approach to solving the semi-finite slab gravity data inversion can be used with constraints. Constructions in the form of an acceptable range of values produce smooth recovered models(Martyshko et al., 2018). 


\section{CONCLUSION}

Inversion modeling produces the optimal calculation referring to the determination of the initial guesses of n0 (1), n0 (2), n0 (3) and n0 (4). If the initial guess is given as input for inversion modeling approaches the field data, the iteration is carried out in only a few steps, if the initial guess is away from the field data then the iteration is done many times. Inversion modeling can produce NAN if the initial guess is very distorted as a result of calculating the matrix resulting in a singular matrix. It can be said that the result of inversion calculation is not accurate because it has a very small reciprocal condition value

\section{REFERENCES}

Abdelrahman, E. S. M., \& Essa, K. S. (2013). A new approach to semi-infinite thin slab depth determination from second moving average residual gravity anomalies. Exploration Geophysics, 44(3), 185-191. https://doi. org/10.1071/EG12045.

Chakravarthi, V., \& Kumar, M. P. (2015). Estimation of multiple density-depth parameters from gravity inversion: Application to detached hanging wall systems of strike limited listric fault morphologies. Geofisica Internacional, 54(1), 49-65. https://doi.org/10.1016/j. gi.2015.04.007.

Eshaghzadeh, A. (2017). Depth Estimation Using the Tilt Angle of Gravity Field due to the SemiInfinite Vertical Cylindrical Source, 2017(1).

Essa, K. S. (2014). New fast least-squares algorithm for estimating the best-fitting parameters due to simple geometric-structures from gravity anomalies. Journal of Advanced Research, 5(1), 57-65. https://doi.org/10.1016/j. jare.2012.11.006.

Martyshko, P., Ladovskii, I., Byzov, D., \& Tsidaev, A. (2018). Gravity Data Inversion with Method of Local Corrections for Finite Elements Models. Geosciences, 8(10), 373. https://doi. org/10.3390/geosciences8100373.

Supriyadi. (2009). STUDI GAYA BERAT RELATIF DI SEMARANG. Jurnal Pendidikan Fisika Indonesia, 5(1), 54-61. Retrieved from http://journal.unnes.ac.id/nju/index.php/JPFI.

Vitale, A., Massa, D. Di, Fedi, M., \& Florio, G. (2015). A NEW INVERSION METHOD OF VERTICAL GRAVITY, i(1990), 166-172.

Yapa, P. Y. A. G. S., Tantrigoda, D. A., \& Pathirana, C. P. S. (2016). Illustrating the Possibility of Modelling the Gravity Anomalies in Terms of Bodies Having Density Vary with Depth, 4(1), 28-35. 